\title{
Analysis of Rock Mass Rating Classification with Using RMR Method
}

\author{
Sukardan Tawil, Muh. Imran Syam, Irianto Uno
}

\begin{abstract}
The looseness that occurs on the road along Tawaeli-Toboli is a very important issue to be examined because the road is the most important axis road in Central Sulawesi - Indonesia. The goal to be achieved is to know the value of the quality of the rocks and their relation to the size of the slope angle on the road, especially at $\mathrm{km} 16$ to $\mathrm{km} 26$ from Palu City, using the Rock Mass Rating (RMR) method. From the analysis of RMR obtained one slope whose description of rocks is poor, namely on slope 3 with a value of RMR of 28 and a medium description with a value of 51 is on slope 1 , for the other six slopes the description of the rock is still a good rock state with values ranging from 63-73. It is concluded that the lowest RMR value requires special attention to be on slope 3. Thus, the friction angle in small rocks, the value of RMR is also small, and the type of soil indicated is bad.
\end{abstract}

Index Terms - Rock Mass Rating (RMR) Tawaeli-Toboli, Rock, Slopes.

\section{INTRODUCTION}

Central Sulawesi is the largest province on the island of Sulawesi with a land area of $68,033 \mathrm{~km}^{2}$ covering the eastern peninsula and parts of the northern peninsula as well as the Togian islands of Tomini Bay and Banggai Islands in Tolo Bay, with an area of the sea is $189,480 \mathrm{~km} 2$, whose territory can be covered by land, sea and air transportation but the favorite is road transportation. But land transportation there are many roads damaged by landslides, especially Tawaeli-Toboli Road Section at km 16 to $\mathrm{km} 26$ from Palu City. The road is very important to be studied because it is the most important axis road in Central Sulawesi that connects Palu with several districts such as Parigi Moutong Regency, Poso Regency, Tojo Unauna Regency, Banggai Regency, North Morowali Regency, and Morowali Regency, and also the road connecting North Sulawesi and South Sulawesi.

Aspects of Engineering Geology is one of the important factors in the assessment of the feasibility of infrastructure development sites, geological data of engineering becomes support in infrastructure development because it provides information characteristic of soil layers or rocks that are useful for planning and structuring the region.

In this study, the slopes that will be analyzed are those on the Tawaeli-Toboli road at km 16 to $\mathrm{km} 26$ from Palu City, which has a steep slope angle with rock material, the method to be used to analyze is the Rock Mass Rating (RMR) method.

\section{A. Location of Research}

Geographically, the research area in Nupobomba District Tanantovea District Donggala Central Sulawesi Province located at coordinates $119^{\circ} 57^{\prime} 40^{\prime \prime} \mathrm{BT}, 0^{\circ} 42^{\prime} 30^{\prime \prime} \mathrm{LS}$, up to $120^{\circ} 00$ ' $30^{\prime \prime} \mathrm{BT}, 0^{\circ} 44^{\prime} 30^{\prime \prime} \mathrm{LS}$. Topographically, the research area is at an altitude ranging from 500 to 1,022 meters above sea level and has a landscape of mountainous complexes with steep slopes, with a length of $10 \mathrm{~km}$ of observation trajectory, as in Fig. 1, 2, and research location Fig. 3.

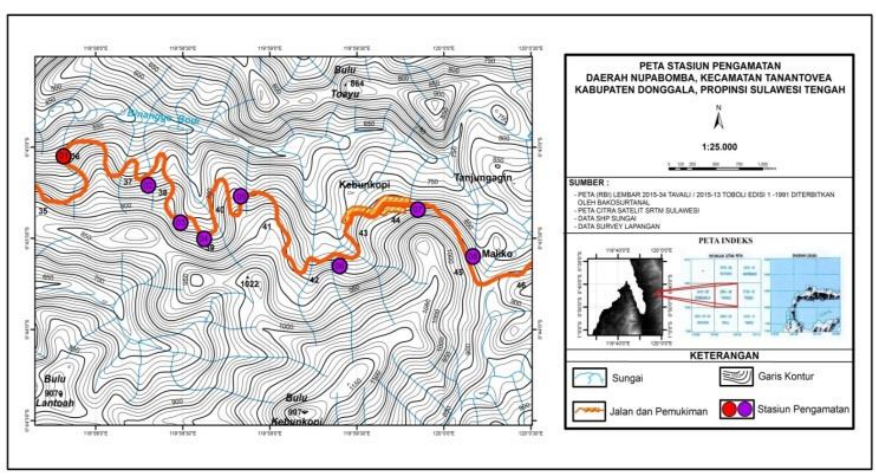

Fig. 1. Map of Observation Station in Nupobomba District Tanantovea District Donggala Central Sulawesi Province [1]

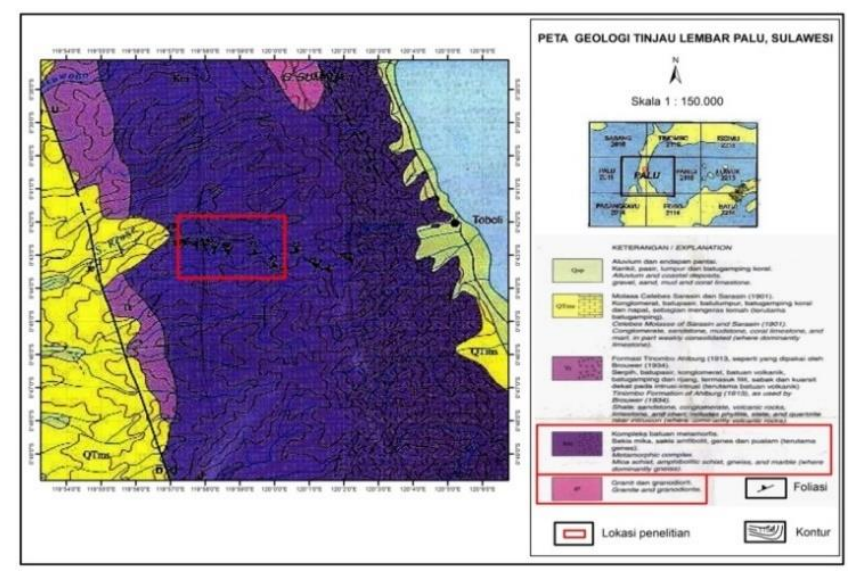

Fig. 2. Regional Geological Map of Palu Sheet, Sulawesi [2] 


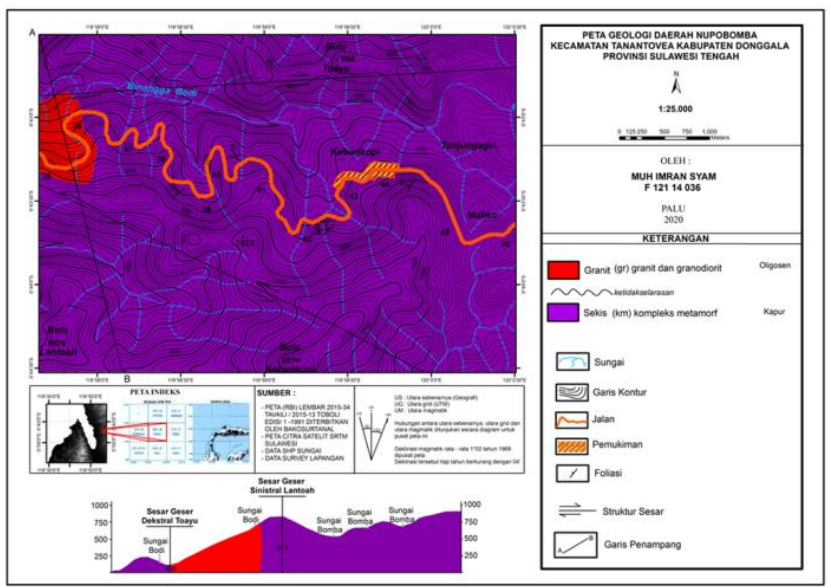

Fig. 3. Geological Map of Research Areas.

\section{LIBRARY REVIEW}

\section{A. The slope of the Soil}

According to Syam [3] that the Slope is the surface of the earth that forms a certain angle of inclination with a horizontal plane, the slope can be formed naturally as well as man-made. Naturally formed slopes for example hillsides and river cliffs, while man-made slopes include: excavations and heaps, embankments, and open-pit mining walls.

The problem of slope stability in a job involving activities and hoarding is an important issue, as it is a matter of the safety of people, equipment, and buildings around the slope, in the mining work, unsafe slopes will interfere with the smooth running of work [4].

Naturally, soil and rocks are generally in equilibrium means that the state of voltage distribution in the soil or rocks is in a stable state. Soil movement is caused by nature and human activities, if the soil or rocks are subject to an activity such as, excavation, decrease, hoarding, transportation, erosion, or other activities that make the disruption of equilibrium, the soil or rocks will try to achieve new equilibrium by reducing the load, especially in the form of avalanches [5]-[7].

To analyze the avalanche it is necessary to first know the voltage system that works on rocks or soil as well as the physical-mechanical properties of the soil and rocks. The rock voltage in its natural mass is horizontal stress, vertical voltage, and water pore pressure. While the mechanical properties that affect the stability of the slope are the angle of deep shear, cohesion, and weight of the contents.

\section{B. Classification of Rock Mass by Method Rock Mass Rating (RMR)}

Classification of the rock mass is used as a tool in analyzing the stability of slopes that connect between science in the field of rock mass with the need for stabilization in various field conditions required, rock mass is divided into several observation points based on similar properties and characteristics, although the mass of rocks is naturally discontinuity, at each observation point that has been divided will have similarities, such as the same type of rocks or the distance of space between the fields of discontinuity is relatively the same.

The method of RMR introduced by Bieniawski [8] has been recognized and often used in geological engineering activities. This RMR method includes 5 parameters as Table I, i.e. [8]:

\section{a. The Pressure power of Rocks}

The pressure of rocks in the RMR Method stated by Uniaxial Compressive Strength (UCS) is the strength of intact rocks obtained from the results of a strong pressure test using hammer test and the test results of the weight of the contents of the rock in units of $\mathrm{Grm} / \mathrm{cm}^{3}$, and to get the $\mathrm{MPa}$ value determined from Schmidt rebound hammer.

\section{b. Rock quality designation (RQD)}

Must first be determined frequency discontinuities, which is a comparison between the number of discontinuities in one of scan-line by the length of scan-line. and used graphics the relationship between RQD with frequency [9], and determination value of UCS by Schmidt hardness, as with Fig. 4.

\section{c. Spacing of discontinuities}

Distance between the spacing of discontinuities defined as the perpendicular distance between two consecutive discontinuities along the measurement line, how to calculate the value of the distance between the spacing of discontinuities uses the average value of field data. The calculated value of RMR, parameter spacing of discontinuities weighted based on its stocky space value of discontinuities spacing.

TABLE I: ClassifiCATION OF RMR AND VALUE OF WEIGHTING, MODIFICATION BY [8]

\begin{tabular}{|c|c|c|c|c|c|c|c|c|c|}
\hline & Uniaxial & Index Point Load & $>10 \mathrm{MPa}$ & 4-10 Mpa & $2-4 \mathrm{MPa}$ & $1-2 \mathrm{MPa}$ & \multicolumn{3}{|c|}{ Not using } \\
\hline \multirow[t]{2}{*}{1} & $\begin{array}{l}\text { Compressive } \\
\text { Strength (UCS) }\end{array}$ & $\begin{array}{c}\text { Uniaxial } \\
\text { Compressive }\end{array}$ & $>250 \mathrm{MPa}$ & $100-250$ & 50-100 Мра & 25-50 Mpa & 5-25 Мра & 1-5 Mpa & $<1 \mathrm{Mpa}$ \\
\hline & \multicolumn{2}{|c|}{ Rating } & 15 & 12 & 7 & 4 & 2 & 1 & 0 \\
\hline \multirow{2}{*}{2} & \multirow{2}{*}{\multicolumn{2}{|c|}{$\begin{array}{c}\text { Rock Quality Designation (RQD) } \\
\text { Rating }\end{array}$}} & $90-100 \%$ & $75-90 \%$ & $50-75 \%$ & $25-50 \%$ & & $<25 \%$ & \\
\hline & & & 20 & 17 & 13 & 8 & & 3 & \\
\hline \multirow{2}{*}{3} & \multirow{2}{*}{\multicolumn{2}{|c|}{$\begin{array}{l}\text { Spacing of discontinuities } \\
\text { Weighted }\end{array}$}} & $>2 \mathrm{~m}$ & $0.6-2 \mathrm{~m}$ & $0.2-0.6 \mathrm{~m}$ & $0.06-0.2 \mathrm{~m}$ & & $<0.06 \mathrm{~m}$ & \\
\hline & & & 20 & 15 & 10 & 8 & & 0 & \\
\hline \multirow[t]{2}{*}{4} & \multicolumn{2}{|c|}{ Condition of Discontinuities } & $\begin{array}{l}\text { Very rude } \\
\text { fresh walls } \\
\text { continuous } \\
\quad \text { solid }\end{array}$ & $\begin{array}{c}\text { Open rough <1 } \\
\text { mm slightly } \\
\text { weathered walls }\end{array}$ & $\begin{array}{c}\text { A little rough } \\
\text { open }<1 \mathrm{~mm} \\
\text { very weathered } \\
\text { walls }\end{array}$ & $\begin{array}{c}\text { Filled Thickness } \\
<5 \mathrm{~mm} \text { open } \\
1-5 \mathrm{~mm} \\
\text { continuously }\end{array}$ & \multicolumn{3}{|c|}{$\begin{array}{l}\text { Loaded material software }>5 \mathrm{~mm} \\
\text { Open }>5 \mathrm{~mm} \text { Continuous }\end{array}$} \\
\hline & \multicolumn{2}{|c|}{ Rating } & 30 & 25 & 20 & 10 & & 0 & \\
\hline \multirow{4}{*}{5} & \multirow{3}{*}{$\begin{array}{l}\text { Groundwater } \\
\text { Condition }\end{array}$} & $\begin{array}{l}\text { Water per } 10 \mathrm{~m} \\
\text { Tunnel length }\end{array}$ & 0 & $<10$ & $25-10$ & $25-125$ & & $>125$ & \\
\hline & & Water pressure & 0 & $<0.1$ & $0.1-0.2$ & $0.2-05$ & & $>0.5$ & \\
\hline & & $\begin{array}{c}\text { General } \\
\text { Conditions }\end{array}$ & Dry & Moist & Watery & Wet & & Flowing & \\
\hline & \multicolumn{2}{|c|}{ Rating } & 15 & 10 & 7 & 4 & & 0 & \\
\hline
\end{tabular}




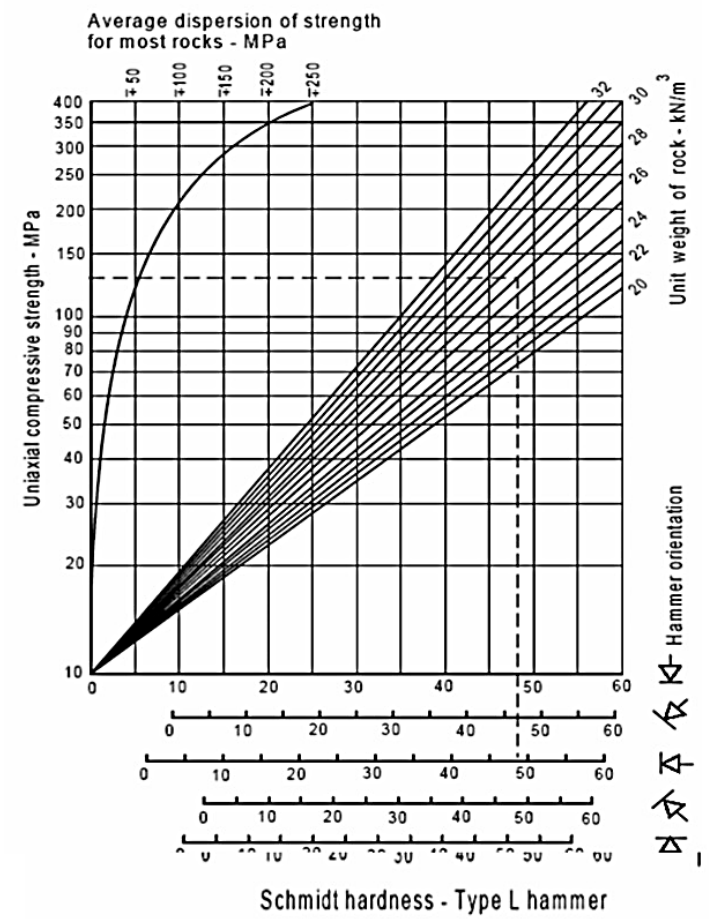

Fig. 4. Determination value of UCS by Schmidt hardness [7].

\section{d. Condition of discontinuities}

Discontinuities are cracks or fractures form in rocks due to a force that works on the rock and has not undergone a shift, the existence of discontinuities will affect the stability of the slopes by the properties of the discontinuities it has. The condition of discontinuities is determined from the description of each field of discontinuity, in the form of Length of discontinuities, openings of discontinuities, roughness, filling, and weathering.

\section{e. Groundwater condition}

Groundwater conditions found in measurements discontinuities identified as one of the following conditions: completely dry, damp, wet, dripping or flowing of water.

\section{METHOD OF RESEARCH}

This study was carried out by the stage of citing literature associated with the RMR method, and field data.
Data retrieval, conducted directly, based on observations of data in the field, and see the physical characteristics and appearance of lithology. Primary data consists of data Uniaxial Compressive Strenght (UCS), the value of RQD, spacing discontinuities, condition of discontinuities, the general condition of groundwater, secondary data of location maps, geological maps, and geological conditions.

Data processing and analysis were conducted by calculating and analyzing using the mass classification of RMR rocks to find out the quality of rock mass and slope conditions. Preparation before data processing, Analysis of parameters - RMR parameters and RMR classification.

\section{RESUlTS AND DISCUSSION}

\section{A. Result of Slope Stability Analysis}

The results of test strong rock pressure obtained by Uniaxial Compressive Strenght (UCS), Rock Quality Design (RQD), the spacing of discontinuities, condition of discontinuities, groundwater condition which is the data Rock mass rating (RMR) carried out on the road TawaeliToboli km 16 up to $\mathrm{km} 26$ from Palu City, by collecting data at 8 observation points stations conducted by JICA [10] together with researchers, as in Table II and Table III.

\section{B. Analysis of Rock}

Analysis of test results as in Table IV, as to give: At station 1 has a value of RMR (Rock Mass Rating) that is worth 51 with the mass class of rocks i.e., class II or rating good rock with mass cohesion of rocks range 300-400 kPa as well as the friction angle of the rock mass with range 35$45^{\circ}$.

Station 2 has a value of RMR that is worth 63 with the mass class of rocks i.e., class II or rating good rock with mass cohesion of rocks range $300-400 \mathrm{kPa}$ as well as the friction angle of the rock mass with range $35-45^{\circ}$.

Station 3 has a value of RMR that is worth 28 with the mass class of rocks i.e., class IV or rating poor rock with mass cohesion of rocks range $100-200 \mathrm{kPa}$ as well as the friction angle of the rock mass with range $15-25^{\circ}$.

TABLE II: DATA UCR, RQD, SPACING OF DISCONTINUITIES, CONDITION OF DISCONTINUITIES, AND GROUNDWATER CONDITION

\begin{tabular}{|c|c|c|c|c|c|c|c|c|c|c|}
\hline \multirow{3}{*}{ Method } & \multirow{3}{*}{\multicolumn{2}{|c|}{ Parameters }} & \multicolumn{8}{|c|}{ Observation Station/Slope } \\
\hline & & & \multicolumn{2}{|l|}{1} & \multicolumn{2}{|l|}{2} & \multicolumn{2}{|l|}{3} & \multicolumn{2}{|l|}{4} \\
\hline & & & Value & Rating & Value & Rating & Value & Rating & Value & Rating \\
\hline \multirow{11}{*}{ RMR } & \multicolumn{2}{|c|}{ UC Strength (MPa) } & 48 & 4 & 45 & 4 & 18 & 2 & 41 & 4 \\
\hline & \multicolumn{2}{|c|}{ RQD (rock quality designation) } & $74 \%$ & 13 & $96 \%$ & 20 & $30 \%$ & 8 & $95 \%$ & 20 \\
\hline & \multicolumn{2}{|c|}{ Spacing of discontinuities } & $600 \mathrm{~mm}$ & 10 & $350 \mathrm{~mm}$ & 10 & $189 \mathrm{~mm}$ & 8 & $140 \mathrm{~mm}$ & 8 \\
\hline & \multirow{6}{*}{$\begin{array}{l}\text { Condition of } \\
\text { discontinuities }\end{array}$} & $\begin{array}{l}\text { a. Length of } \\
\text { discontinuities }\end{array}$ & $\begin{array}{c}(2,6 \mathrm{~m}) / 1- \\
3 \mathrm{~m}\end{array}$ & 4 & $<1 \mathrm{~m}$ & 6 & $(3,4 \mathrm{~m}) / 3-10 \mathrm{~m}$ & 2 & $<1 \mathrm{~m}$ & 6 \\
\hline & & b. Openings & $>5 \mathrm{~mm}$ & 0 & $>5 \mathrm{~mm}$ & 0 & $>5 \mathrm{~mm}$ & 0 & None & 6 \\
\hline & & c. Roughness & Very rude & 6 & $\begin{array}{l}\text { A little } \\
\text { rough }\end{array}$ & 3 & Rough & 5 & Rough & 5 \\
\hline & & d. Charging & $\begin{array}{c}\text { Hard }>5 \\
\mathrm{~mm}\end{array}$ & 2 & $\begin{array}{c}\text { Soft }>5 \\
\mathrm{~mm}\end{array}$ & 0 & Hard $>5 \mathrm{~mm}$ & 2 & None & 6 \\
\hline & & e. Weathering & $\begin{array}{c}\text { A little } \\
\text { weathered }\end{array}$ & 5 & $\begin{array}{c}\text { A little } \\
\text { weathered }\end{array}$ & 5 & Very weathered & 1 & Weathered & 3 \\
\hline & & $\begin{array}{l}\text { Number of } \\
\text { ratings }\end{array}$ & 17 & & 14 & & 10 & & 26 & \\
\hline & \multicolumn{2}{|c|}{ Groundwater condition } & Wet & 7 & Dry & 15 & Flowing & 0 & Moist & 10 \\
\hline & \multicolumn{2}{|c|}{ Total RMR } & \multicolumn{2}{|l|}{51} & \multicolumn{2}{|l|}{63} & 28 & & \multicolumn{2}{|l|}{68} \\
\hline
\end{tabular}


TABLE III: DATA UCR, RQD, SPACING OF DISCONTINUITIES, CONDITION OF DISCONTINUITIES, AND GROUNDWATER CONDITION

\begin{tabular}{|c|c|c|c|c|c|c|c|c|c|c|}
\hline \multirow{3}{*}{ Method } & \multirow{3}{*}{\multicolumn{2}{|c|}{ Parameters }} & \multicolumn{8}{|c|}{ Observation Station/Slope } \\
\hline & & & \multicolumn{2}{|c|}{5} & \multicolumn{2}{|c|}{6} & \multicolumn{2}{|l|}{7} & \multicolumn{2}{|l|}{8} \\
\hline & & & Value & Rating & Value & Rating & Value & Rating & Value & Rating \\
\hline \multirow{11}{*}{ RMR } & \multicolumn{2}{|c|}{ UC Strength (MPa) } & 35 & 4 & 85 & 7 & 140 & 12 & 45 & 4 \\
\hline & \multicolumn{2}{|c|}{ RQD (rock quality designation) } & $94 \%$ & 20 & $93 \%$ & 20 & $87 \%$ & 17 & $94 \%$ & 20 \\
\hline & \multicolumn{2}{|c|}{ Spacing of discontinuities } & $460 \mathrm{~mm}$ & 10 & $180 \mathrm{~mm}$ & 8 & $260 \mathrm{~mm}$ & 10 & $440 \mathrm{~mm}$ & 10 \\
\hline & \multirow{2}{*}{\multicolumn{2}{|c|}{$\begin{array}{l}\text { a. Length of } \\
\text { discontinuities } \\
\text { b. Openings }\end{array}$}} & $<1 \mathrm{~m}$ & 6 & $\begin{array}{c}(2,10 \mathrm{~m}) / 1- \\
3 \mathrm{~m}\end{array}$ & 4 & $<1 \mathrm{~m}$ & 6 & $\begin{array}{c}(2,5 \mathrm{~m}) / \\
1-3 \mathrm{~m}\end{array}$ & 4 \\
\hline & & & None & 6 & $1-5 \mathrm{~mm}$ & 1 & None & 6 & $1-5 \mathrm{~mm}$ & 1 \\
\hline & \multirow{4}{*}{$\begin{array}{l}\text { Condition of } \\
\text { discontinuities }\end{array}$} & c. Roughness & $\begin{array}{l}\text { A little } \\
\text { rough }\end{array}$ & 3 & $\begin{array}{l}\text { A little } \\
\text { rough }\end{array}$ & 3 & A little rough & 3 & $\begin{array}{l}\text { A little } \\
\text { rough }\end{array}$ & 6 \\
\hline & & d. Charging & None & 6 & $\begin{array}{c}\text { Hard }<5 \\
\mathrm{~mm}\end{array}$ & 4 & None & 6 & None & 6 \\
\hline & & e. Weathering & Weathere & 3 & $\begin{array}{c}\text { Not } \\
\text { weathered }\end{array}$ & 6 & Weathered & 3 & Weathered & 3 \\
\hline & & $\begin{array}{l}\text { Number of } \\
\text { ratings }\end{array}$ & \multicolumn{2}{|c|}{24} & \multicolumn{2}{|l|}{18} & \multicolumn{2}{|l|}{24} & \multicolumn{2}{|l|}{20} \\
\hline & \multicolumn{2}{|c|}{ Groundwater condition } & Moist & 10 & Dry & 15 & Moist & 10 & Moist & 10 \\
\hline & \multicolumn{2}{|l|}{ Total RMR } & \multicolumn{2}{|c|}{68} & \multicolumn{2}{|l|}{68} & \multicolumn{2}{|l|}{73} & \multicolumn{2}{|c|}{64} \\
\hline \multicolumn{11}{|c|}{ TABLE IV: THE RESULT OF PRP AND SMR METHOD } \\
\hline & Method & ST 01 & ST 02 & ST 03 & ST 04 & ST 05 & ST 06 & ST 07 & \multicolumn{2}{|c|}{ ST 08} \\
\hline \multicolumn{2}{|r|}{ RMR } & 51 & 63 & 28 & 68 & 68 & 68 & 73 & \multicolumn{2}{|c|}{64} \\
\hline \multicolumn{2}{|c|}{ Rock Mass Class } & III & II & IV & II & II & II & II & \multicolumn{2}{|c|}{ II } \\
\hline Des & ription of rocks & Medium & Good & Bad & Good & Good & Good & Good & & od \\
\hline Rock N & sss Cohesion $(\mathrm{kPa})$ & $200-300$ & $\begin{array}{c}300- \\
400\end{array}$ & $100-200$ & $300-400$ & $\begin{array}{c}300- \\
400\end{array}$ & $300-400$ & $300-400$ & 300 & -400 \\
\hline Friction & Angle of Rock Mas & $25^{\circ}-35^{\circ}$ & $35^{\circ}-45^{\circ}$ & $15^{\circ}-25^{\circ}$ & $35^{\circ}-45^{\circ}$ & $35^{\circ}-45^{\circ}$ & $35^{\circ}-45^{\circ}$ & $35^{\circ}-45^{\circ}$ & $35^{\circ}$ & $-45^{\circ}$ \\
\hline
\end{tabular}

Station 4 has a value of RMR that is worth 68 with the mass class of rocks i.e., class II or rating good rock with mass cohesion of rocks range $300-400 \mathrm{kPa}$ as well as the friction angle of the rock mass with range $35-45^{\circ}$.

By based on the theory Alberta [11], then station 5 has a value of RMR that is worth 68 with the mass class of rocks i.e., class II or rating good rock with mass cohesion of rocks range $300-400 \mathrm{kPa}$ as well as the friction angle of the rock mass with range $35-45^{\circ}$. Station 6 has a value of RMR that is worth 68 with the mass class of rocks i.e., class II or rating good rock with mass cohesion of rocks range 300-400 $\mathrm{kPa}$ as well as the friction angle of the rock mass with range $35-45^{\circ}$.

Station 7 has a value of RMR that is worth 73 with the mass class of rocks i.e., class II or rating good rock with mass cohesion of rocks range $300-400 \mathrm{kPa}$ as well as the friction angle of the rock mass with range $35-45^{\circ}$.

Station 8 has a value of RMR that is worth 64 with the mass class of rocks i.e., class II or rating good rock with mass cohesion of rocks range $300-400 \mathrm{kPa}$ as well as the friction angle of the rock mass with range $35-45^{\circ}$.

\section{CONCLUSION}

Based on the results of RMR analysis conducted on-road sections Tawaeli - Toboli km 16 up to km 26 from Palu City, exactly area of Nupabomba, Tanantovea District, Donggala District, Central Sulawesi got one slope whose description of the rocks is bad i.e., being on slopes 3 with value 28 , and medium description with value 51 is on the slopes 1, for sixth slopes description of the rocks is still good rock with value range 63-73. So the lowest RMR value that requires special attention is on slope 3 . The friction angle of rock is small so the RMR value is also small, and the soil type is getting worse

\section{REFERENCES}

[1] Bakosumtanal. "Map of Rupabumi Indonesia, Tvaili Sheet (Scala 1:50.000)". Cibinong, Bogor. 1991.

[2] R. Sukamto, "Geological Map Review Palu Sheet, Sulawesi". Bandung. 1973.

[3] M. Romana, "New adjustment Rating for Applications of Bieniawski Classification to Slope". Mexico: ISRM. 1995.

[4] M. Syam, and Heryanto. "Slope Stability Analysis Based on Slope Mass Rating Value In Sukamaju Village, Tenggarong Seberang, Kutai Kartanegara, East Kalimantan. Samarinda”, Geology, Fakulty of Engineering, University of Mulawarman. 2018.

[5] J. Zhao, "Rock Mechanics for Civil Engineers". Laussane: Swiss Federal Institute of Technology.

[6] M. Rai, S. Kramadibrata, and R. K. Wattimena, "Rock Mechanics". Bandung: ITB. 2014.

[7] E. Hoek, "Practical Rock Engineering". Canada: Capilano Crescent. 2000 .

[8] Z. Bieniawski, "Engineering Rock Mass Classification". New York: John Wiley \& Sons. 1989.

[9] J. Hudson, J. Harrison, "Engineering Rock Mechanics". Amsterdam. Pp. 116-121, 1997.

[10] JICA, "Draft Final Report Volume III Feasibility Study For Tawaeli - Toboli”. Yachiyo Engineering CO., LTD. 1998.

[11] H. Alberta, "Slope Stability Analysis and Slope Reduction On Liwa City Boundary Road Section - Simpang Gunung Kemala, Taman Nasional Bukit Barisan Selatan, West Lampung”, Bandar Lampung: Fakulty of Engineering, University of Lampung. 2016. 